\title{
(Lack of) oral hygiene care for hospitalized elderly patients
}

\author{
(Des) cuidado na higiene bucal do idoso em hospitalização \\ (Des) cuidado en la higiene oral de los ancianos hospitalizados
}

Elaine de Oliveira Souza Fonseca'
ORCID: 0000-0003-3083-3209

Larissa Chaves Pedreira'

ORCID: 0000-0001-8939-324X

Rudval Souza da Silva',"1

ORCID: 0000-0002-7991-8804

Rosimere Ferreira Santana"' ORCID: 0000-0002-4593-3715

João Tavares ${ }^{\text {IV }}$

ORCID: 0000-0003-3027-7978

Maria Manuela Martins ${ }^{\vee}$

ORCID: 0000-0003-1527-9940

Roberta Pereira Góes

ORCID: 0000-0001-7746-5592

'Universidade Federal da Bahia. Salvador, Bahia, Brazil. "Universidade do Estado da Bahia. Senhor do Bonfim, Bahia, Brazil.

I' Universidade Federal Fluminense. Niterói, Rio de Janeiro, Brazil.

" Universidade de Aveiro, Escola Superior de Saúde. Aveiro, Portugal.

${ }^{v}$ Escola Superior de Enfermagem do Porto. Porto, Portugal.

How to cite this article: Fonseca EOS, Pedreira LC, Silva RS, Santana RF, Tavares J, Martins MM, et al. (Lack of) oral hygiene care for hospitalized elderly patients. Rev Bras Enferm. 2021;74(Suppl 2):e20200415. doi: http://dx.doi.org/10.1590/0034-7167-2020-0415

\section{Corresponding author:}

Elaine de Oliveira Souza Fonseca

E-mail: eofonseca@uneb.br

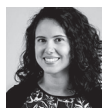

EDITOR IN CHIEF: Dulce Barbosa ASSOCIATE EDITOR: Alexandre Balsanelli

\section{ABSTRACT}

Objective: to analyze the oral hygiene care for hospitalized elderly patients provided by the nursing staff. Method: this is a qualitative, exploratory-descriptive study carried out in a university hospital, with the participation of 35 professionals from the nursing staff. Data collection was carried out through semi-structured interviews, explored through thematic content analysis. Results: two categories emerged: The oral hygiene of hospitalized elderly patients as an extension of body care and Barriers in (lack of) care with the oral hygiene of hospitalized elderly patients, with two subcategories: The oral hygiene and dental prosthesis technique performed divergently; Care hampered by deficit of materials and human resources. Final considerations: this study showed weaknesses in the oral hygiene care of hospitalized elderly patients, promoting reflections on the practice informed in data and management actions, allowing recommendations of care standards for the nursing staff.

Descriptors: Aged; Oral Hygiene; Hospitalization; Geriatric Nursing; Standard of Care.

\section{RESUMO}

Objetivo: analisar o cuidado desenvolvido pela equipe de enfermagem à higiene bucal da pessoa idosa hospitalizada. Método: estudo qualitativo, exploratório-descritivo, realizado em um hospital universitário, com a participação de 35 profissionais da equipe de enfermagem. A coleta de dados foi por meio de entrevistas semiestruturadas, exploradas por meio da Análise de Conteúdo Temática. Resultados: emergiram duas categorias: A higiene bucal da pessoa idosa hospitalizada enquanto extensão do cuidado corporal e Barreiras no (des) cuidado com a higiene bucal de idosos hospitalizados, com duas subcategorias: Técnica da higiene da boca e da prótese dentária realizada de forma divergente; O cuidado prejudicado pelo déficit de materiais e de recursos humanos. Considerações finais: o estudo demonstrou fragilidades no cuidado à higiene bucal de idosos hospitalizados promovendo reflexões sobre a prática informada nos dados e ações de gerência, permitindo recomendações de padrões de cuidado para a equipe de enfermagem.

Descritores: Idoso; Higiene Bucal; Hospitalização; Cuidado de Enfermagem ao Idoso Hospitalizado; Padrão de Cuidado.

\section{RESUMEN}

Objetivo: analizar los cuidados que brinda el equipo de enfermería a la higiene bucal de los ancianos hospitalizados. Método: estudio cualitativo, exploratorio-descriptivo, realizado en un hospital universitario, con la participación de 35 profesionales del equipo de enfermería. La recolección de datos se realizó mediante entrevistas semiestructuradas, exploradas mediante análisis de contenido temático. Resultados: surgieron dos categorías: la higiene bucal del anciano hospitalizado como extensión del cuidado corporal y barreras en el (des) cuidado con la higiene bucal del anciano hospitalizado, con dos subcategorías: Higiene bucal y técnica de prótesis dental realizada de manera divergente; El cuidado perjudicado por el déficit de materiales y recursos humanos. Consideraciones finales: el estudio demostró debilidades en el cuidado de la higiene bucal de ancianos hospitalizados, promoviendo reflexiones sobre la práctica informada en los datos y acciones de manejo, permitiendo recomendaciones de estándares de cuidado para el equipo de enfermería.

Descriptores: Anciano; Higiene Bucal; Hospitalización; Cuidados de Enfermería para Ancianos Hospitalizados; Nivel de Atención. 


\section{INTRODUCTION}

Population aging is a global reality, for which we still need to look for ways to deal with it in care settings. The world report on aging and health highlights that by 2050 the world's population of people over 60 will double ${ }^{(1)}$. Brazil, in the medium term, will present a super population of elderly people, with growth of around $3 \%$ per year, reaching $33 \%$ of the Brazilian population in $2050^{(2)}$.

The health care of elderly people has presented itself as a challenge, due, among other things, to their socioeconomic diversity and comorbidities, needing to rethink the health system ${ }^{(3)}$. One form of action, in this perspective, is disease prevention measures, with oral hygiene care being one of the possible strategies, especially with regard to hospitalized elderly patients. The World Health Organization emphasizes that the oral health of elderly people is neglected, especially in the less favored social classes, in developed or non-developed countries, constituting a relevant action to be undertaken to achieve healthy aging ${ }^{(1)}$.

Caring for the oral health of elderly people is particularly relevant due to the predisposing factors that result from primary (e.g., decrease in saliva, less efficacy of the cough reflex, gingival recession, and pulpal atresia) and secondary aging (e.g., neurocognitive disorders, pluripatology, and polymedication), leaving these people vulnerable to injuries in the oral cavity. Furthermore, considering this multifactorial nature, these people, especially the most dependent, experience difficulties that prevent a good performance of hygiene ${ }^{(4-5)}$.

In this regard, hospitalized elderly patients, often bedridden, and with pathologies that can compromise swallowing should receive care aimed at protective actions to mouth integrity. Likewise, attention to oral hygiene with independent elderly people is an excellent opportunity for health education, as it allows detecting oral lesions, poor adaptation to prostheses and other situations.

Promoting discussions in the field of nursing about aspects related to oral hygiene is relevant, since the staff is the one most involved with hygienic care and has a strong influence on people's oral health. However, despite this, it is necessary to involve the nursing staff in oral hygiene care standards development so that their practical interventions and guidelines for self-care in patients achieve the best results ${ }^{(6)}$.

Faced with this problem, the question was: how is nursing care developed for the oral hygiene of hospitalized elderly patients?

\section{OBJECTIVE}

To analyze the care provided by the nursing staff to the oral hygiene of hospitalized elderly patients.

\section{METHODS}

\section{Ethical aspects}

This work was linked to a matrix project. Since it is a study with human beings, the determinations of Resolutions 466/2012 and 510/2016 of the Brazilian National Health Council (Conselho Nacional de Saúde) were respected. To this end, it was submitted to the Research Ethics Committee of the institution in which the study was located, with a favorable Opinion on June 7, 2018.

In order to safeguard participants' anonymity and confidentiality, an identification system by alphanumeric codes was adopted from the abbreviation of the "ICU" sector for Intensive Care Unit and "WAR" for ward, followed by a period and letter " $N$ " for nurses and " $T$ " for nursing technicians.

\section{Type of study}

This is a qualitative, exploratory-descriptive study. It aims to understand the subjective experiences of a phenomenon related to care practice ${ }^{(7)}$.

\section{Methodological procedures}

Data collection took place in two stages. In the first, individual interviews were conducted in a private place, respecting participants' availability. The audio-recorded interviews had an average time of 12 minutes per participant. Immediately after completion, they were transcribed in full and organized for analysis. Collection closure considered the data saturation principle, when there was a depletion of new elements to be analyzed, prevailing the clarity of the object of study ${ }^{(8)}$.

To carry out the interviews, a form structured in two parts was used: the first with sociodemographic data and on professionals' performance in the sector, such as length of service, professional category and performance or not of any training offered by the hospital institution focused on oral health care of hospitalized elderly people. The second part covered issues about nursing care and oral hygiene care, seeking to identify from the materials used until the moment of the actions of this task and the difficulties and/or facilities that the staff encountered in this care.

In the second stage, a documentary research was carried out aiming to know nursing staff sizing in the locus units, and the records of the nursing staff's daily distribution book were consulted to better observe the relationship between the nursing team and oral care provision. Such knowledge was important to understand some statements, which related to the lack of time to provide this care.

\section{Study setting}

This study was carried out at a public teaching hospital integrated with the Unified Health System (Sistema Único de Saúde) in a capital of northeastern Brazil. It was conducted in two Intensive Care Units (ICU I and II) and in an inpatient unit. ICUs assisted adult patients and elderly people with medical and surgical clinic demands, respectively with nine and 10 beds. The inpatient unit welcomed adult patients/elderly people with chronic illnesses, being characterized as a medical clinic unit, with a total of 23 beds.

\section{Data source}

Nursing staff professionals in assistance activity according to the scale of work in the locus units during the collection period 
were included. Professionals with less than three months of experience were excluded, understanding that, for this investigation, there was a need for the staff to understand the sector's hygienic care routine. Professionals on vacation, on period of sick leave or other, besides those in exclusively administrative activities were also excluded.

\section{Data collection and organization}

Data collection was carried out by the main author between September and October 2018 through semi-structured interviews. The recruitment of nursing professionals occurred in all shifts and during the data collection period, on the service scale, consisting only of nurses and nursing technicians. Participants were invited to participate in the research individually, and after acceptance, they were requested to sign an Informed Consent Form.

\section{Data analysis}

For data organization and systematization, the thematic content analysis technique was adopted, where it was possible to analyze and categorize participants'statements ${ }^{(9)}$. To this end, after material transcription, the research corpus was initially submitted to pre-analysis, using as references in the literature on the subject and the research question as a guide, resulting in the main clippings that made up registration units.

In the second exploratory stage, the clippings obtained were manually coded according to convergent and divergent sections, giving rise to units of meaning, represented by categories and subcategories, which led to the third stage, the moment of data interpretation based on critical and reflective inferences, in addition to documentary information and data from the relevant literature.

Two thematic categories emerged: The oral hygiene of hospitalized elderly patients as an extension of body care and Barriers in (lack of) care with the oral hygiene of hospitalized elderly patients. The last category was subdivided into two subcategories: The oral hygiene and dental prosthesis technique performed divergently; Care hampered by deficit of materials and human resources.

\section{RESULTS}

Thus, 35 professionals participated in the study, 19 from ICUs and 16 from ward, being 20 nurses and 15 nursing technicians. Of these professionals, 27 were female and eight were male, with an average age of 34 years. Concerning time working in the sector, the average was 1 year and 3 months. With regards to having some training on oral health care, only 10 of them, all from ICU, reported having taken an oral hygiene guidance course, taught by the dental team that works at the hospital.

Analysis of categories and subcategories made it possible to understand how oral hygiene care for hospitalized elderly patients is developed. The first category revealed that oral hygiene care for hospitalized elderly patients is performed as an extension of body hygiene, and the performance of other moments of oral hygiene were conditioned to the demand of the unit, or when patient/companion themselves performed. The institution's standard operating protocol was disregarded, as well as elderly people's routine such as oral hygiene after meals and before bedtime, in addition to health education on the importance of this habit. This practice was repeated both in ICUs and in wards, as shown in the registration units below.

Chart 1 - Oral care of hospitalized elderly patients as an extension of body care

\begin{tabular}{|c|}
\hline Fragments of the interviews \\
\hline $\begin{array}{l}\text { [Oral hygiene] is performed only in the bath, where it is more } \\
\text { prioritized. During the day, the team forgets to perform. (ICU.N13) }\end{array}$ \\
\hline $\begin{array}{l}\text { Oral hygiene is performed once a day in the morning, in the bath. } \\
\text { We can't keep it after lunch [...], because the demand is very high. } \\
\text { (WAR.T2) }\end{array}$ \\
\hline $\begin{array}{l}\text { [...] care for oral hygiene is delegated to the patient or companion, } \\
\text { and we do not supervise. During the bath, it usually happens. } \\
\text { (WAR.N4) }\end{array}$ \\
\hline $\begin{array}{l}\text { [...] at bath time, whether in bed or not, there is oral hygiene. We } \\
\text { have so much demand that we don't always guarantee it at other } \\
\text { times. (ICU.T11) }\end{array}$ \\
\hline
\end{tabular}

The second category entitled "Barriers in (lack of) oral hygiene care of hospitalized elderly patients" pointed out that there is no uniformity for oral hygiene of these people, since the nursing staff has demonstrated empirical care. It was also observed deficit of material and human resources that further weaken this care. In this way, two subcategories were revealed: The oral hygiene and dental prosthesis technique performed divergently; Care hampered by deficit of materials and human resources.

Chart 2 - Barriers in (lack of) care with the oral hygiene of hospitalized elderly patients: the oral hygiene and dental prosthesis technique performed divergently

\begin{tabular}{|c|}
\hline Fragments of the interviews \\
\hline $\begin{array}{l}\text { Oral hygiene is performed once, which is at bath time and, depending } \\
\text { on, [...] they have companions who sometimes bring the materials. } \\
\text { We put chlorhexidine in the gauze and perform oral hygiene [...]. } \\
\text { Sometimes, they remove the dental prosthesis, wrap it in paper } \\
\text { towels, and do their own hygiene with paste and brush. (WAR.T4) }\end{array}$ \\
\hline $\begin{array}{l}\text { [...] I will not characterize a frequency of oral hygiene, because it } \\
\text { is due to the need. (WAR.N1) }\end{array}$ \\
\hline $\begin{array}{l}\text { [...] I do oral hygiene in the morning. In the afternoon I use only } \\
\text { water, or if I have to, I use toothpaste [...]. For the dental prosthesis, } \\
\text { I put on a mask, put on the glove and do the hygiene, with the } \\
\text { brush or even with soap and water. (ICU.T13) }\end{array}$ \\
\hline $\begin{array}{l}\text { Oral hygiene is prescribed twice a day, and then do it in the morning } \\
\text { in the bath and at night in hygiene [...], usually using chlorhexidine. } \\
\text { We clean the prosthesis with a brush and paste, and keep it in a } \\
\text { transparent box next to the patients' belongings. (ICU.N22) }\end{array}$ \\
\hline
\end{tabular}

It was found that the hospital institution does not always provide the necessary materials for correct oral hygiene. Therefore, the staff requests purchase for elderly people's family members, a 
common reality in clinical practice. In the statements, professionals also point out losses in oral care activities for elderly people due to high demand for activities in the sector.

Chart 3 - Barriers in (lack of) care with the oral hygiene of hospitalized elderly patients: care hampered by deficit of materials and human resources

\section{Fragments of the interviews}

The difficulty in assisting oral hygiene is that many patients come without the necessary hygiene materials [...]. As I have many activities, I get involved in other demands, delegating oral health to nursing technicians [...]. (WAR.N8)

A difficulty for oral hygiene is lack of material. The brush and toothpaste, the family has to bring them, the hospital doesn't have. [...] another difficulty in performing oral care is due to the exhaustive routine in the unit [...] elderly people demand a lot of care. (ICU.N12)

A difficulty for oral health is lack of material. (ICU.T9)

The lack of some materials, supplies even from the hospital itself, compromises this care [...]. There is still an incipience in relation to oral care, due to the demand, for the number of patients for a nursing technician. So, we do the basics [...]. (WAR.T6)

\section{DISCUSSION}

Regarding participants' characterization, women figured prominently. This finding is related to the historical construction of women's participation in the nursing work field, in which professional work was established as an extension of domestic work, demonstrating that gender relations conditioned nursing practice ${ }^{(10)}$. Participants were mostly young, and with fewer years of experience in the labor sector. However, this data did not influence the overall result, since their statements were convergent with that of professionals with a long time in the service, regarding elderly people's oral hygiene actions.

Regarding training in oral health, it was registered that, among the 35 participants, only 10 underwent it, all of whom were ICU workers. It is inferred that this situation occurs due to the attempt to avoid pneumonia associated with mechanical ventilation, a major risk factor in these units. Despite this, there was no difference in the reports between those who did the training and those who did not. It should be noted that there must be an understanding of oral health care for elderly people in hospital settings. Nursing has a relevant action in this assistance that must go beyond ICUs ${ }^{(6)}$.

Thus, the emerging need for continuing education is revealed as an important strategy for new learning, updating knowledge, and guaranteeing the process of continuous training of health professionals ${ }^{(11)}$. However, it should be noted that, together with this, means must be offered so that the activities discussed in continuing education are carried out.

With regard to new knowledge, it is worth highlighting the importance of recognizing the most modern and suitable materials for oral hygiene according to the characteristics of the elderly people's oral cavity, in addition to knowing how to observe whether or not they have dentition, use of dental prosthesis, hospital devices or mucosal lesions. Furthermore, it is important to pay attention to adaptive needs taking into account the individualized hygiene care routine of each elderly people.

Regarding bath, a study carried out in São Paulo with 1,413 elderly people, aiming to classify the need for care to these people, identifying their functional demands, showed that bath was an activity deemed necessary once a day ${ }^{(12)}$. Therefore, oral hygiene, appearing as an extension of body hygiene in the speeches, was described as performed once a day by most participants. In Brazil, there is the daily practice of hygienic care with the bath, in the hospital setting, performed routinely in the morning shift and once a day, except for some patients' needs. However, oral hygiene should preferably occur after meals, or at three times daily and with the appropriate indications, according to the type of patient and unit ${ }^{(13)}$.

It is also noteworthy that this care must be disconnected from the bath and, when not possible, it must be performed before body hygiene ${ }^{(14)}$. This, however, should not be the only moment of oral hygiene, a situation recognized by the investigated professionals, as observed in the statements.

A study showed that oral hygiene performed twice a day in non-ventilated patients decreased the incidence of hospitalacquired pneumonia from 105 to 8.3 cases per 100 patient-days in the first year of the survey, estimating that 13 lives were saved in 19 months ${ }^{(14)}$. The authors also concluded that when nurses motivate the staff to help with oral hygiene, it can be avoided costs associated with these pneumonias, saving 2.84 million dollars with this care.

Oral hygiene frequency depends on each patient's diet and needs, and should be assessed by a dentist or nurse. Furthermore, when on an oral diet, it should be performed three times a day, after meals ${ }^{(13)}$. Therefore, performing this hygiene only at bath time translates into a (lack of) oral health care for elderly people, since it should be performed with greater regularity. It is also understood that there is a need to be prioritized before elderly people fall asleep, since salivary flow is lower at night and it is relevant to reduce bacterial load at this time, although night care with oral hygiene is not part of routine in the units studied, a fact that was also observed in a study carried out in Canada that sought to explore how nurses who work at night provided this care to hospitalized elderly patients ${ }^{(6)}$.

Therefore, the statements showed a lack of uniformity regarding the oral care performed by the staff, where each professional has his own way and frequency of performance, although most do it at bath time. A study carried out with 231 nursing professionals from nine intensive care units in southern Brazil, when seeking to assess the influence of oral health protocols and the methods used to provide this care, demonstrated that there is a great variability in the frequency of use of materials and instruments for oral hygiene, even among professionals in a single ICU, emphasizing the absence of protocols or lack of adherence to existing regulations ${ }^{(15)}$.

Decrease in oral hygiene frequency was also observed in a multicenter study carried out in several regions of Brazil, which revealed that the frequency in ICUs varied from none (6\%), one (23.2\%), two $(29,4 \%)$, three (35\%) and up to four $(11.9 \%)$ times a day ${ }^{(16)}$.

The nursing staff at work on screen justified the occurrence of irregularity in oral hygiene frequency due to the excessive 
demands of care faced in the work routine. However, data from the documentary collection showed that ICU sizing was presented as recommended by the Resolution of the Federal Nursing Council $543 / 2017$, representing a nursing professional for 1.33 patients ${ }^{(17)}$. In the ward, there was a restriction of staff, mainly at night. This distribution should be assessed for suitability, to the detriment of service demand, especially when there are large numbers of elderly people with care dependence.

Therefore, in order to carry out a reliable staff sizing in the unit, information about the profile of patients and the activities required, such as time of procedures and interventions, administrative and support activities for relatives of inpatients, common in ICUs, are necessary ${ }^{(18)}$.

The complexity and specificity inherent to the hospitalization of elderly people, generally implies a greater need for nursing care. The aging of society and the increase in the number of chronic diseases are linked to the degree of dependence of elderly people on the care provided by health professionals. It is possible to affirm that the growth of the elderly population with high dependence on care impacts the workload of the nursing staff(19).

However, since the staff sizing is adequate in the investigated ICU, attention is drawn to the need to give visibility to this topic, alerting professionals to the need for this care, in addition to continuing education. In this context, authors point out that nurses have distanced themselves from maintenance care assistance, delegating this activity to nursing technicians, as they end up more involved in technological and managerial activities ${ }^{(5)}$.

Carrying out this work was carried out in two environments, ward and ICU, precisely because they present different care profiles in relation to the care for the elderly people's oral cavity. In ICUs, the presence of patients using artificial ventilation provides the need for differentiated care, as it is based on the attempt to control the infection by preventing pneumonia associated with mechanical ventilation.

Therefore, it needs attention and specific measures, with the use of appropriate materials for the mechanical and chemical control of oral biofilm, with a priority view in assisting the oral hygiene of elderly people. However, it was observed in the statements the use of only chemical control in intubated patients and only mechanical control in those on spontaneous ventilation, in line with what is recommended in the literature. In all intensive care patients, aqueous chlorhexidine should be used every 12 hours, and the mechanical method should be performed only by nurses or dentists ${ }^{(13)}$.

A systematic review study, with the objective of describing the research produced by nurses on this assistance in critical units, recommended the mechanical control of dental biofilm by brushing with soft bristles and using chemical control using $0.12 \%$ chlorhexidine in intubated patients ${ }^{(20)}$. Another study carried out through a questionnaire sent to multidisciplinary staff that worked in ICUs in Brazilian regions showed that $80.8 \%$ of the ICUs surveyed used aqueous oral chlorhexidine, with a concentration between 0.12 and $0.2 \%{ }^{(17)}$.

It is noteworthy that the same basis and priority of assistance provided to patients in intensive care should be carried out in independent elderly people, who are more commonly seen in inpatient sectors, but who, in the same way, may be weakened. A study carried out in the United States, with the intention of developing a standardized assessment of oral care in adults dependent on hospital care outside the ICU environment, estimated that $44 \%$ to $65 \%$ of patients did not receive adequate oral care ${ }^{(21)}$.

In this regard, in relation to carrying out care protocols, its use during permanent education and its adaptation to local demands could resolve some problems, unifying nursing actions through evidence from the literature. At the collection site, for instance, many elderly inpatients are from the countryside, some from rural areas, with low education and precarious economic conditions, requiring special attention to their specific needs, including education and health.

A study carried out in an American hospital identified that there was only an oral hygiene protocol for ICU patients, showing that nurses were more concerned with this sector. Thus, it implemented and developed a set of actions to care for oral hygiene of all adult patients admitted to wards. These actions included guidelines for using the mechanical and chemical method every day after meals and before bedtime, in which it was possible to achieve a $59 \%$ reduction in new cases of pneumonia(22).

It is relevant to present updated hygienic care practices also in terms of dental prosthesis use, as elderly people are vulnerable due to their own senility. Dental prosthesis causes qualitative and quantitative changes in oral biofilm, increasing the predisposition of patients to develop inflammatory pathologies and processes, even though they know that, in many moments their hygiene is neglected $^{(23)}$.

Furthermore, it is necessary to take advantage of these moments to carry out health education and to encourage elderly people, family members and caregivers for self-care.

Regarding dental prosthesis, professionals' statements also revealed flaws in this care. A Canadian study also demonstrated, through interviews with nurses at night wards, that dental cleaning activities featured a variety of routines for such care: cleaning with brush and toothpaste; immersion in water with a cleaning tablet; immersion in pure water; dry storage without cleaning and with cleaning using a cotton swab soaked with mouthwash; keeping in patients' mouths overnight without cleaning ${ }^{(24)}$.

The specific hygiene and storage precautions that are necessary for good oral health to exist also showed flaws, since it was reported that dental prostheses were cleaned with toothpaste and/ or aqueous chlorhexine. Concerning dental prosthesis hygiene, the ideal is to carry out a mechanical and chemical method for biofilm control. The mechanical method is performed by means of a prosthetic brush with neutral soap and rinsed under running water, and the chemical method must be performed by immersing the prostheses in substances such as sodium hypochlorite, alkaline peroxides, diluted acids, enzymes and chlorhexidine ${ }^{(25)}$.

In addition to the necessary supplies for cleaning the dental prosthesis, this device also needs a place for storage that is part of your hygienic care. It is noteworthy that in hospital settings, gauze should not be used as a form of packaging, as it causes losses, since it is a daily resource used as material for body cleaning and dressings, being common in hospital waste. Thus, the gauze camouflages the dental prosthesis, leading to the risk of disposal (26).

Lack of material resources for oral hygiene care was observed in the speeches, in which the majority of professionals reported the unavailability of a toothbrush, important for the mechanical removal of oral biofilm, requiring the family of elderly people to 
purchase this material. To facilitate oral care provision, the availability of materials is essential ${ }^{(24)}$. Moreover, it can be a motivator for this care to be carried out or oriented.

An alternative of providing cost control in prosthesis hygiene assistance was pointed out in a study with the use of antiseptic soaps. In the study that aimed to assess the physical and biological properties of an acrylic resin, based on prostheses, after immersion in antiseptic soaps, it was successful in controlling Candida albicans, which can be a cheap and easy procedure to prevent stomatitis by dental prosthesis ${ }^{(27)}$.

Thus, nursing practices must be based on consolidated actions, with periodic reviews and updates of each care, allowing offering an excellent care. Patients with self-care deficit, as is the case of some elderly people, need a nursing staff involved with a demonstrably adequate assistance with oral hygiene in a systematic and updated manner ${ }^{(20)}$, as well as in health education for independent elderly people. It is noteworthy that preserving patients' autonomy must not surpass the guarantee of adequate oral hygiene results and that the daily verification of patients, in order to guarantee good care, does not hurt the dignity of independent individuals and should be an encouraged practice across the nursing staff( ${ }^{(6)}$.

\section{Study limitation}

A limitation of this work was that data collection occurred at only one public hospital and these results cannot be treated as generalities. Another gap presented was the non-deepening of the use of each reported hygiene material, which could bring a different usage profile for each input.

It is also noteworthy that the short time of the interviews, due to the need for the professional to return to work activities, may have led to the restriction of reflections by the staff. However, even though it is brief, it revealed how this care has been carried out.

\section{Contributions to nursing, health, and public health}

This study offers contributions to patients and organizations. In the case of patients, their visibility can improve oral hygiene care, performed by or assisted by nursing, reducing adverse events related to this (lack of) care, and promoting self-care. For organizations, taking as a reflex improvement to patients, it is advisable to reduce costs with complications arising from a (lack of) care with oral hygiene. It is noteworthy that the data of this work were reported to the researched institution and, in a scientific journey format, it was possible to promote discussions with the nursing and hospital management staff, contributing to improvements in gerontological care.

Thus, it also allows reflections for constructing instruments and protocols for this nursing care practice by using strategies, through continuous health education, in order to raise awareness of the staff to updated care, based on data and mainly sensitive to the peculiar dimension of aging.

\section{FINAL CONSIDERATIONS}

This study revealed that, in the hospital environment, the nursing staff performs oral hygiene care for hospitalized elderly patients centered at bath time. There were gaps in this assistance revealing a need for standardization as there was a divergence in the care reports.

It was pointed out as a deficit of inputs in the institution and excessive demands in caring for elderly patients hospitalized. This reflects a need to manage routine activities and the indispensability of materials for oral care, and with dental prosthesis as an inherent resource for hygienic care, so that excellent care is allowed, understanding that these generate actions to prevent pathologies and injuries in hospitalization.

Thus, nursing must be attentive to offering hospital care based on actions to prevent/reduce problems and/or oral problems, based on the best scientific evidence, to generate comfort, quality of care, improvements in hospitalization and still offer lower costs to Brazilian health.

\section{FUNDING}

Bahia State Research Support Foundation (FAPESB - Fundação de Amparo à Pesquisa do Estado da Bahia) financed this study in the form of a Master's scholarship for Elaine de Oliveira Souza Fonseca.

\section{ACKNOWLEDGMENT}

We are grateful to the entire nursing staff at the hospital, where this study was carried out, which made themselves available to carry out this work.

\section{REFERENCES}

1. World Health Organization. World report on ageing and health [Internet]. 2015 [cited 2020 Apr 23]. p. 260. Available from: https://www.who. int/ageing/publications/world-report-2015/en/.

2. Ervatti LR, Borges GM JA. IBGE. Mudança demográfica no Brasil no início do século XXI : subsídios para as projeções da população [Internet]. 2015 [cited 2020 Apr 23]. 156 p. Available from: https://biblioteca.ibge.gov.br/index.php/biblioteca-catalogo?view=detalhes\&id=293322.

3. Wachs LS, Nunes BP, Soares MU, Facchini LA, Thumé E. Prevalence of home care and associated factors in the Brazilian elderly population. Cad Saude Publica. 2016;32(3). doi: 10.1590/0102-311X00048515

4. Danckert R, Ryan A, Plummer V, Williams C. Hospitalisation impacts on oral hygiene: an audit of oral hygiene in a metropolitan health service. Scand J Caring Sci. 2016;30(1):129-34. doi:10.1111/scs.12230

5. Passos SSS, Carvalho ESS, Sadigursky D. Higiene oral ao paciente dependente hospitalizado: percepções de uma equipe enfermagem. Rev Pesqui: Cuid Fundam[Internet]. 2014 [cited 2020 Apr 23];6(4):1396-408. Available from: http://www.index-f.com/pesquisa/2014/r61396.php 
6. Coker E, Ploeg J, Kaasalainen S, Carter N. Nurses' oral hygiene care practices with hospitalised older adults in postacute settings. Int J Older People Nurs [Internet]. 2017 [cited 2020 Apr 24];12(1). Available from: http://www.ncbi.nlm.nih.gov/pubmed/27353475

7. Minayo MCS, Deslandes SF, Gomes RC. Pesquisa social: teoria, método e criatividade. 34th ed. Vozes. Petrópolis; 2015.108 p.

8. Minayo MCS. Amostragem e saturação em pesquisa qualitativa: consensos e controvérsias. Rev Pesqui Qual [Internet]. 2017 [cited 2020 Apr 23];5(7):01-12. Available from: https://editora.sepq.org.br/index.php/rpq/article/view/82/59

9. Bardin L. Análise de conteúdo. Edições 70. Lisboa; 2016.

10. Santos TA, Melo CMM. Valor do trabalho da enfermeira. EDUFBA. Salvador; 2019.

11. Viana DS, Viana DMS, Nogueira CA, Araújo RS, Vieira RM, Rennó HMS, et al. A educação permanente em saúde na perspectiva do enfermeiro na estratégia de saúde da família. Rev Enferm Centro-Oeste Min [Internet]. 2015 [cited 2020 Apr 23];5(2):1658-68. Available from: http:// www.seer.ufsj.edu.br/index.php/recom/article/view/470

12. Nunes DP, Brito TRP, Corona LP, Alexandre TS, Duarte YAO. Elderly and caregiver demand: proposal for a care need classification. Rev Bras Enferm. 2018;71 2:844-50. doi: 10.1590/0034-7167-2017-0123

13. Associação de Medicina Intensiva Brasileira (AMIB). Procedimento Operacional Padrão (POP) de Higiene Bucal [Internet]. 2019 [cited 2020 Apr 23]. p. 1-8. Available from: https://www.amib.org.br/noticia/nid/procedimento-operacional-padrao-pop-de-higiene-bucal-amib-2019/

14. Munro S, Baker D. Reducing missed oral care opportunities to prevent non-ventilator associated hospital acquired pneumonia at the Department of Veterans Affairs. Appl Nurs Res [Internet]. 2018 [cited 2020 Apr 23];44:48-53. Available from: https://www.ncbi.nlm.nih.gov/ pubmed/30389059

15. Blum DFC, Munaretto J, Baeder FMG, Gomez J, Castro CPP, Bona AD. Influence of dentistry professionals and oral health assistance protocols on intensive care unit nursing staff: a survey study. Rev Bras Ter Intensiva [Internet]. 2017[cited 2020 Sep 03];29(3):391-3. Available from: https://www.scielo.br/pdf/rbti/v29n3/en_0103-507X-rbti-29-03-0391.pdf.

16. Blum DFC, Silva JAS, Baeder FM, Bona A. The practice of dentistry in intensive care units in Brazil. Rev Bras Ter Intensiva. 2018;30(3):327-32. doi: 10.5935/0103-507x.20180044

17. Conselho Federal de Enfermagem. Resolução no 543/2017, de 18 de abril de 2017. Parâmetros para o Dimensionamento do Quadro de Profissionais de Enfermagem nos serviços/locais em que são realizadas atividades de enfermagem. [Internet]. 2017[cited 2020 Apr 23]. 119 p. Available from: http://www.cofen.gov.br/resolucao-cofen-5432017_51440.html

18. Souza VS, Inoue KC, Oliveira JLC, Magalhães AMM, Martins EAP, Matsuda LM. Sizing of the nursing staff in adult intensive therapy. Rev Min Enferm. 2018;22(e-1121):1-6. doi: 10.5935/1415-2762.20180056

19. Lima AFC, Fugulin FMT, Castilho V, Nomura FH, Gaidzinski RR. Contribuição da documentação eletrônica de enfermagem para aferição dos custos dos cuidados de higiene corporal. J Health Informatics [Internet]. 2012[cited 2020 Apr 23];4(Número Especial-SIIENF):108-13. Available from: http://www.jhi-sbis.saude.ws/ojs-jhi/index.php/jhi-sbis/article/view/239

20. Nogueira JW da S, Jesus CAC de. Oral hygene of the patient admitted in an intensive care unit : integrative review. Rev Eletrôn Enferm. 2017;19(e46):1-16. doi: 10.5216/ree.v19.41480

21. Nguh J. Oral care practice guidelines for the care-dependent hospitalized adult outside of the intensive care unit setting. J Interprof Educ Pract. 2016;4:59-67. doi: 10.1016/j.xjep.2016.05.004

22. Quinn B, Baker DL. Comprehensive oral care helps prevent hospital-acquired nonventilator pneumonia. Am Nurse Today. $2015 ; 10$ (3):18-23. Available from: https://www.myamericannurse.com/wp-content/uploads/2015/03/ant3-CE-Oral-Care-225.pdf

23. Bastos PL, Mesquita TC, Ottoboni GS, Figueiredo VMG. Métodos de higienização em próteses dentais removíveis: uma revisão de literatura. J Dent Public Heal. 2015;6(2):129-37. doi: 10.17267/2238-2720revbahianaodonto.v5i2.683

24. Coker E, Ploeg J, Kaasalainen S, Carter N. Observations of oral hygiene care interventions provided by nurses to hospitalized older people. Geriatr Nurs (Minneap). 2017;38(1):17-21. doi:10.1016/j.gerinurse.2016.06.018

25. Araújo LMP, Cruz MJC, Meneses SS. Materials and methods used in total prosthesis hygiene: literature review. Rev Interfaces: Saúde Hum Tecnol [Internet]. 2016 [cited 2020 Apr 23];3(9):18-24. Available from: http://www.interfaces.leaosampaio.edu.br

26. Fonseca EOS, Pedreira LC, Gomes NP, Amaral JB, Virgens IR, Santos FC. Nursing care for storage of dental prostheses in hospitalized elderly patients. Acta Paul Enferm. 2019;32(4):442-8. doi: 10.1590/1982-0194201900060

27. Zoccolotti JO, Tasso CO, Arbeláez MIA, Malavolta IF, Pereira ECS, Esteves CSG, et al. Properties of an acrylic resin after immersion in antiseptic soaps: low-cost, easy-access procedure for the prevention of denture stomatitis. PLoS One [Internet]. 2018[cited 2020 Apr 23];13(8):e0203187. Available from: https://www.ncbi.nlm.nih.gov/pubmed/30161256 